\title{
THE COMPREHENSIVE APPROACH TO THE ENTERPRISE'S ADAPTATION IN THE PROCESS OF DEVELOPMENT: MANAGERIAL ASPECT
}

\author{
Nataliia MARYNENKO' \\ Ternopil Ivan Puluj National Technical University, Ukraine
}

\begin{abstract}
The purpose of the paper is to develop a comprehensive approach to managing the enterprise's adaptive development within the production and economic organizations (PEO). The methods of economic and mathematical modeling are used for assessing the enterprise's adaptive development capacity. Methodology. The research is based on the developing the approach to managing problem situations emergence at the stages of the enterprises' pre-adaptation, co-adaptation and adaptation within PEO, introducing the equation for the adaptive development capacity implementation efficiency determination and identifying the stages of the industrial enterprises' adaptive development forecasting. Results. The comprehensive approach to the enterprise's adaptation in the process of development, which consists of the problem situations management, determination of the enterprise's adaptive development capacity and forecasting of the enterprises' adaptive development is introduced. Practical implications. The application of the proposed approach for identifying the problem situations to emerge at the stages of the enterprises' pre-adaptation, co-adaptation and adaptation within PEO will make it possible to avoid such situations emergence at the enterprise or, if the situation has already occurred, to adjust managerial decisions for doing so. The use of the ratio for assessing the relevance of situation to emerge will improve the decision making process concerning the enterprises' adaptation to macroeconomic challenges effectiveness, save time and resources on the reaction which is required by the external environment due to the situation's relevance and will significantly facilitate the assessment of the adaptive measures being undertaken effectiveness during the enterprise's development within the PEO. A criterion of the adaptive development capacity implementation efficiency will allow to determine the impact of the managerial decisions concerning the adaptive capacity (with all identified constraints) implementation on the level of such capacity. Fuzzy-multiple descriptions are used as a tool for recognizing the managerial decisions efficiency level. The results of the analysis of the proposed enterprise's adaptation coefficient value testify about the correctness (or not) of the adaptive decisions and actions being undertaken. Value/originality. The development of a well-grounded approach of the enterprise's adaptation to the external environment under modern conditions is an urgent task as there is a likelihood of new and unpredicted factors to impact its activities, so effective decisions on adaptation are necessary to be made quickly. The application of the developed comprehensive approach by enterprises will make it possible for them to effectively adapt to the dynamic and challenging market environment.
\end{abstract}

Key words: management, adaptive development, forecasting, adaptive capacity, problem situation, external environment impact.

JEL Classification: M1, M21, C53, D2, D74, D81

\section{Introduction}

The external environment rapid development and new challenging market conditions result in the necessity of developing an adaptive approach to the enterprises functioning. Success of the PEO, which is a form of economic organization that incorporates different by their ownership, legal form, production and commercial activity industrial enterprises and other companies, e.g., banks, financial institutions etc. (Aliieksieiev, 2002) in many aspects is determined by an aggregate indicator of the enterprises' adaptation to the external environment changes. Appearance of new technologies and technological processes in the world imposes new requirements for the rapid development of relevant branches of industry making enterprises to adapt to these changes in order to maintain or achieve an optimal state

Corresponding author:

${ }^{1}$ Department of Economics and Finance, Ternopil Ivan Puluj National Technical University.

E-mail: n_marynenko@ukr.net 
of the PEO functioning while external conditions tend to change. The ability of the PEO to adapt is determined by the strength of the relationships between enterprises within it and their impact on the adaptation process final result.

The aim of the paper is to present a comprehensive approach to managing the enterprise's adaptive development within the PEO.

\section{Identification of problem situations emerging during the enterprises development}

The pace of the company's external environment change faster than the management system reaction to them. That's why it is of urgency to identify and remove possible problem situations to occur in time. For doing so, few issues should be taken into consideration: 1) companies might have significant discrepancy of technological, industrial and institutional capacity to the environment requirements; 2) activity under uncertainty enforces enterprises to reconstruct internal industrial relationships and to improve the internal structure without proper consideration of the entity's external environment etc.

By their nature and type the problem situations emerge at different stages of the enterprises' adaptive development within a specified PEO. Therefore, approach, the use of which would make it possible to identify and correct problem situations emerging at the stages of the enterprises' pre-adaptation, co-adaptation and adaptation is proposed. Its main components are as follows:

1. Enterprise's pre-adaptation process analysis within the PEO, which includes the identification of the enterprise's active and passive components as well as the enterprise's management subsystems efficiency analysis with the adjustment of management subsystems operations if necessary (identification and removal of management subsystems problem situations).

2. Identification of potential areas for development: the emergence of problem situations in interrelations between the enterprises within the PEO (e.g., functions duplication, conflict of interests, functional processes deficiency) which leads to the inconsistency zones emergence between the enterprises.

3. Resolving of the inconsistency between enterprises by their co-adaptation (by applying the inconsistency level management with the help of specific management functions performance efficiency criteria) and adaptation within the PEO (by finding out the nature of necessary changes in accordance with the external environment requirements, ranking of those changes by their urgency and identifying the reaction type).

During the adaptation of the PEO to the changes in the external environment the potential for problem situations emergence also exists when the system can randomly react to different disturbances. With the aim of avoiding this, the ranking of events that are to be responded quickly is of need.
Based on the study of Baranenko and Shemetov (2004), the assessment of the situation's relevance should be carried out by the following equation:

$$
\delta T=\frac{\Delta T_{\text {res }}}{\Delta T_{\text {red }}},
$$

where $\delta T$ - is the assessment of the situation's relevance; $\delta T_{\text {res }}$ - is the time remaining before the onset of situation; $\delta T_{\text {red }}$ - is the time required to take action concerning the targeted impact on the processes occurring in the external environment.

The application of this assessment method will improve the decision making process concerning the enterprises' adaptation to macroeconomic challenges effectiveness, save time and resources on the reaction which is required by the external environment due to the situation's relevance and will significantly facilitate the assessment of the adaptive measures being undertaken effectiveness during the enterprise's development within the PEO.

4. The enterprises' activities mutual coordination within the PEO and the reaction rate identification as a result of the measures stated above.

\section{Determination of the enterprise's adaptive development capacity}

The adaptive development process and enterprise ongoing management are directly related to the adaptive capacity of the company, its size and structural components. Adaptive capacity, which is shaped by both qualitative and quantitative indicators, is a key condition for the implementation of adaptive management under the changing external environment, and the most important factor that contributes to the enterprise competitiveness increase in the new functioning circumstances.

First of all, it is required to create a system of constraints concerning the use of adaptive capacity by accenting on its financial, production, technological and labor components for fitting the approved managerial decisions on adaptive development.

The constraints determined above should meet the main aim of the managerial decisions on adaptation implementation, which is the profit to be continuously received in terms of the external environment dynamics.

$$
\sum_{i=1}^{T} \sum_{i=1}^{n} \sum_{j=1}^{q_{j}} B_{i}^{j}(t) y_{i}^{j} \geq 0,
$$

where $B_{i}^{j}(t) y_{i}^{j}$ - is the net profit in the selected time period $t$, received as a result of the approved managerial decisions on adaptive measures implementation $t$ within the chosen variant of implementation $j, t=0 \ldots T$.

Next, the impact of the approved managerial decisions concerning the adaptive capacity (with all identified constraints) implementation on the level of such capacity is to be determined. For doing so, it is necessary to use a criterion of the adaptive development capacity implementation efficiency which is a correlation between the level of satisfaction of those needs that emerge at the 
enterprise under the impact of the changing external environment (by the use of the previously determined financial, technological, industrial and labour components and their constraints which are to be taken into account during the decision-making process on adaptive management) and the costs of their provision:

$$
E=\left(\sum_{i=1}^{n} Y_{i}^{j} / \sum_{j=1}^{q} C_{i}^{j}\right) \rightarrow \max ,
$$

where $E$ - is the adaptive development capacity implementation efficiency;

$$
\sum_{i=1}^{n} Y_{i}^{j} \text { - is the level of satisfaction of those needs that }
$$

emerge at the enterprise under the impact of the changing external environment;

$\sum_{j=1}^{q} C_{i}^{j}$ - are the costs for the needs provision.

For preserving the reliability of the obtained results the use of fuzzy-multiple descriptions as a tool for recognizing the $E$ level values is the most appropriate one. The fuzzymultiple descriptions are to be used in order to replace the point numeric values on their quality characteristics, such as "low-medium-high". Scale of the E possible point numeric values is the interval $(0,1)$ as a standard five-fuzzy classifier (Loyko and Yefanova, 2005).

Based on the presented system of constraints concerning the use of the development adaptive capacity with its determined financial, production, technological and labor components, we represent the $E$ as a fuzzy figure, the model of which is as follows:

$$
E=H(A, F, P, S, K, M) \text {, }
$$

where $A$ - are the possible types of the adaptive development capacity resources;

$F$ - is the financial resource;

$P-$ is the production resource.

$S$ - is the technological resource;

$K$ - is the labor resource;

$M$ - is a term-set of possible assessments of each model's component level:

$M=\{$ Very low level $(V L L)$, Low level $(L L)$, Average level $(A L)$, High level $(H L)$, Very high level $(V H L)\}$.

$\mathrm{H}$ - is the symbol of the indicators system hierarchy.

The assessment of the adaptive development capacity implementation efficiency involves a comparison of qualitative and quantitative characteristics of the $E$ model components.

\section{Forecasting the enterprises' adaptive development}

The development of a well-grounded forecast of the enterprise's adaptation to the external environment under modern conditions is of great necessity as the likelihood of new and unpredicted factors impacting its activities and decision-making on adaptation emergence should be taken into account.

The stages of the industrial enterprises' adaptive development forecasting are as follows:
1 . The current period adaptive development pre-forecast evaluation stage.

2. The enterprise adaptation coefficient real value calculation.

3. Concluding about the effectiveness of adaptive development selected policy.

4. The determination of external and internal factors affecting the enterprise's adaptive development.

5. Ranking of these factors by their importance.

6. The enterprise's adaptive development scenarios simulation.

7. The adaptive expectations model development.

8. The moving equilibrium coefficient calculation.

9. The enterprise's adaptive development results forecast.

For forecasting the enterprise's adaptive development within $\mathrm{PEO}$ we propose to use the adaptation coefficient $C_{a}$, which reflects the relationship of external and internal environment of the enterprise and which would maintain the relative equality of two processes - the dynamics of the environmental factors impact on the enterprise and its reaction on such an impact under the process of adaptation to changes.

For obtaining the current value of the enterprise's adaptation coefficient to the changes being provoked by the environment (macroeconomic one) at the pre-forecasting stage, the ratio of the index of the company's sales to the index of the country's industrial production is introduced:

$$
C_{a}=I_{c} / I_{i p} \text {, }
$$

where $I_{c}-$ is the index of the enterprise's sales in the current period;

$I_{i p}$ - is the index of the country's industrial production in the current period.

The economic essence of this ratio is as follows: the impact of macroeconomic instability on the company's activities results in the emergence of the same changes in the company (when the business activity decrease in the country the enterprises' sales reduce as well). In case of the coefficient value to be equal to or greater than one, we may conclude about the positive effects of the adaptive measures being undertaken. Conversely, if the coefficient value is less than one it means that the company made wrong adaptive decisions and actions or did not undertake any (Revenko, Lyba, Moshkina, 2013).

The satisfactory value of the coefficient testifies about a balanced policy concerning the development and implementation of adaptive measures which should be maintained in the future. In case of the coefficient value to be unsatisfactory (not only for the present ratio but also as to the calculation of other groups of internal and external environments indicators), the areas to be focused on when complying the moving equilibrium with the environment should be indicated.

\section{Conclusions}

The comprehensive approach to the enterprise's adaptation in the process of development, which consists of such constituents as the problem situations 
management, determination of the enterprise's adaptive development capacity and forecasting of the enterprises' adaptive development, is introduced.

The approach to managing problem situations emergence at the stages of the enterprises' pre-adaptation, co-adaptation and adaptation within the PEO is offered. It is determined that the industrial enterprise's adaptive development management within the PEO at the pre-adaptation stage should employ its structural components and management subsystems effectiveness analysis for identifying some problems emergence (e.g., duplication of functions and processes, conflicts of interest etc.) in the interrelation between the enterprises within the PEO. In order to maintain the viability of the PEO as a system the ratio for assessing the relevance of the situation to emerge is proposed.

The system of constraints concerning the use of adaptive development capacity is identified and the criterion of the adaptive development capacity implementation efficiency is obtained.

The approach to forecasting the industrial enterprise's adaptive development is proposed in the paper as well as the determination of the current value of the enterprise's coefficient of adaptation to changes in the external environment.

\section{References}

Alieksieiev, I. V. (2002). Strategies and regulation for industrial-economic structures innovation development. Dissertation, Institute for Economics and Forecasting of the National Academy of Sciences of Ukraine.

Baranenko, S. P. \& Shemetov, V. V. (2004). Strategic sustainability of the enterprise : monograph. Moscow: Tsentrpolygraph.

Loyko, V. I., \& Yefanova, N. V. (2005). Approach to the evaluation of the risk integral index of integrated production systems. Scientific Journal of KubSAU, 3(11.) Retrieved from: http:/ /ej.kubagro.ru /2005/03/18/

Revenko, D. S., Lyba, V. A., \& Moshkina, I. K. (2013). Diagnostic method of stability of enterprise operation in the macroeconomic volatility. Economics and management of machine-building industry: problems of theory and practice, $3(23), 34-43$.

\section{Наталия МАРИНЕНКО}

\section{КОМПЛЕКСНЫЙ ПОДХОД К РЕШЕНИЮ ПРОБЛЕМЫ АДАПТАЦИИ ПРЕДПРИЯТИЙ В ПРОЦЕССЕ РАЗВИТИЯ: УПРАВЛЕНЧЕСКИЙ АСПЕКТ}

Аннотация. Целью работы является разработка комплексного подхода к управлению адаптивным развитием предприятия в рамках производственно-хозяйственных структур (ПХС). Для оценки их адаптационного потенциала были использованы методы экономико-математического моделирования. Методика. Исследование основано на разработке подхода к управлению проблемными ситуациями, которые возникают на этапах предварительной адаптации, коадаптации и адаптации предприятий в рамках ПХС, использовании уравнения для определения эффективности реализации потенциала адаптивного развития и определении этапов прогнозирования адаптивного развития промышленных предприятий. Результаты. Предложен комплексный подход к адаптации предприятия в процессе развития, который состоит из управления проблемными ситуациями, определения потенциала адаптационного развития предприятия и прогнозирования адаптивного развития предприятий. Практическое значение. Применение предлагаемого подхода для выявления проблемных ситуаций, которые возникают на этапах предварительной адаптации, коадаптации и адаптации предприятий в рамках ПХС позволит избежать возникновения таких ситуаций на предприятии или, если ситуация уже возникла, скорректировать управленческие решения для устранения этой ситуации. Использование уравнения для оценки актуальности ситуации, которая возникает, улучшит процесс принятия решений, касающихся эффективности адаптации предприятий к макроэкономическим вызовам, сэкономит время и ресурсы на реакцию на ситуацию и будет в значительной степени способствовать оценке эффективности предпринимаемых адаптивных мер в процессе развития предприятия в рамках ПХС. Критерий эффективности реализации потенциала адаптивного развития позволяет определить влияние осуществляемых управленческих решений, касающихся адаптационного потенциала (со всеми выявленными ограничениями), на его уровень. Нечетко-множественные описания используются в качестве инструмента для выявления уровня эффективности управленческого решения. Результаты анализа значения предлагаемого коэффициента адаптации предприятия свидетельствуют о правильности (или нет) предпринимаемых адаптивных решений и действий. Значение/оригинальность. Разработка обоснованного подхода к адаптации предприятия к внешней среде в современных условиях является актуальной задачей, поскольку постоянно существует вероятность влияния новых и непредсказуемых факторов на деятельность предприятия и необходимость принятия быстрых эффективных адапционных решений. Применение предприятиями разработанного комплексного подхода позволит им эффективно адаптироваться к постоянно изменяющимся условиям рыночной среды. 